\title{
Pulmonary complications of Type 1 (insulin-dependent) diabetic patients
}

\author{
K.Strojek $^{1}$, D.Ziora ${ }^{2}$, J.W. Sroczynski ${ }^{1}$ and K. Oklek ${ }^{2}$ \\ ${ }^{1}$ Department of Internal and Occupational Diseases and ${ }^{2}$ Department of Pneumonology, Silesian Academy of Medicine, Zabrze, Poland
}

Summary. We have investigated the influence of diabetes mellitus including the presence of late complications on the pulmonary system. To check this relationship 31 Type 1 (insulin-dependent) diabetic patients (mean age $30.6 \pm 5.32$ years, mean duration of diabetes $12.9 \pm$ 5.05 years) were admitted into the trial and compared with 18 control subjects. Pulmonary function tests were measured including spirometric parameters, diffusing capacity, specific diffusing capacity and dynamic compliance measured at 20 and 60 breaths per min. No disturbance of the spirometric parameters was observed in the diabetic patients. Diffusing capacity in the diabetic patients with complications was significantly lower than in both the diabetic patients without complications and the control group $(81.2 \pm 16.2 \%, 104 \pm$ $13.7 \%, 99.3 \pm 2.8 \% ; p<0.001, p<0.005$ respectively). Specific diffusing capacity was significantly lower in the diabetic patients than in the control subjects $(80.3 \pm 13.1 \%$ vs $89.4 \pm 12.9 \% ; p<0.05)$. In the group with late complications specific diffusing capacity was lower than in the group without complications $(69.7 \pm 9.17 \% ; 87.2 \pm 10.7 \%$, respectively; $p<0.001$ ). Dynamic compliance at 20 breaths per min in diabetic patients was $84.06 \pm 17.08 \%$ vs $95.2 \pm 11.59 \%$ in the control subjects $(p<0.05)$. It was particularly low in the group with late complications $80.6 \pm 13.2 \%$ and patients with metabolic poor control, $80.3 \pm 12.02 \%$ (both $p<0.005$ vs the control group). Dynamic compliance at 60 breaths per min was $60.1 \pm 15.0 \%$ as compared to $83.2 \pm 13.3 \%$ in the control group $(p<0.001)$. We conclude that the disturbances of dynamic compliance may be due to the local mosaic abnormalities of lung elasticity, caused by the non-enzymatic glycation of protein. Disturbances in diffusion in diabetic patients confirm the presence of microangiopathy in pulmonary vessels.

Key words: Diabetes mellitus, late complications, pulmonary function.
Insulin as treatment for diabetes mellitus has given patients an extended and increased quality of life. However, it does not prevent the occurrence of late complications such as micro- and macroangiopathy or diabetic neuropathy. In studies to date the influence of diabetes on the pulmonary system has not been definitely determined. Previous studies have been performed on only a small number of patients [1,2] or did not exclude subjects suffering from other diseases which could affect the pulmonary system [3, 4]. A dense network of capillary vessels in the lungs may change in formation during the course of microangiopathy. The connective tissue structure of alveoli may be subjected to non-enzymatic glycation of proteins which may, in turn affect its function.

The aim of this study was to assess the influence of diabetes upon the pulmonary system. Anatomical changes in lungs, even these early changes, can modify pulmonary function. Therefore we applied pulmonary function tests which allow a precise analysis of the status of the pulmonary system to be made. In addition, we examined the influence of metabolic control as well as late diabetic complications on pulmonary system function.

\section{Subjects and methods}

The study consisted of 31 Type 1 diabetic patients (17 men and 17 women) who were never smokers from the Out-patient Clinic for Diabetic Patients in Zabrze. Patients suffering from diseases associated with cardio-pulmonary system malfunction were excluded. The control group consisted of 18 healthy volunteers (nine men and nine women) who were never smokers matched for height, weight, age and sex (Table 1). Diabetic patients in the study were then grouped according to the following entry criteria 1 . Clinical manifestation of late complications. The presence of retinopathy (as determined by ophthalmoscope examination), nephropathy (defined as microalbuminuria greater than $80 \mu \mathrm{g} / \mathrm{ml}$ detected by the Micro-Bumintest, Ames-Miles Division, Elkhart, Ind., USA, serum creatinine level above $130 \mu \mathrm{mol} / \mathrm{L}$ or both) or diabetic neuropathy (diagnosed by clinical examination) were determined. These patients were placed into the subgroup of 12 subjects (six men and six women) with 
Table 1. Characteristics of patient groups and control subjects (mean $\pm \mathrm{SD}$ )

\begin{tabular}{|c|c|c|c|c|c|c|c|c|}
\hline & $\mathrm{n}$ & $\begin{array}{l}\text { Age } \\
\text { (years) }\end{array}$ & $\begin{array}{l}\text { Duration of } \\
\text { diabetes } \\
\text { (years) }\end{array}$ & $\begin{array}{l}\mathrm{HbA}_{1} \\
(\%)\end{array}$ & $\begin{array}{l}\text { Fructosamine } \\
(\mu \mathrm{mol} / \mathrm{l})\end{array}$ & $\begin{array}{l}\text { BMI } \\
\left(\mathrm{kg} / \mathrm{m}^{2}\right)\end{array}$ & $\begin{array}{l}\text { Weight } \\
(\mathrm{kg})\end{array}$ & $\begin{array}{l}\text { Height } \\
(\mathrm{cm})\end{array}$ \\
\hline Control subjects & 18 & $30 \pm 4$ & & & & $22.4 \pm 2.1$ & $63.8 \pm 11.0$ & $171 \pm 7$ \\
\hline Diabetic patients & 31 & $30 \pm 5$ & $12 \pm 5$ & $9.05 \pm 1.22$ & $453 \pm 128$ & $23.5 \pm 2.4$ & $66.0 \pm 10.7$ & $167 \pm 9$ \\
\hline Subgroup with complications & 12 & $29 \pm 6$ & $11 \pm 5$ & $9.07 \pm 1.34$ & $436 \pm 141$ & $23.3 \pm 2.8$ & $63.8 \pm 9.69$ & $164 \pm 1$ \\
\hline Subgroup without complications & 19 & $30 \pm 5$ & $12 \pm 5$ & $9.04 \pm 1.17$ & $461 \pm 122$ & $23.6 \pm 2.3$ & $63.7 \pm 11.9$ & $168 \pm 9$ \\
\hline Good metabolic control & 22 & $30 \pm 6$ & $11 \pm 4$ & $7.10 \pm 1.27$ & $373 \pm 170$ & $23.4 \pm 2.7$ & $65.3 \pm 12.1$ & $166 \pm 11$ \\
\hline
\end{tabular}

Non-diabetic reference ranges: $\mathrm{HbA}_{1}<8 \%$; fructosamine $<289 \mu \mathrm{mol} / 1$

Table 2. Spirometric and flow-volume curve parameters in patient groups and control subjects (mean $\pm \mathrm{SD}$ )

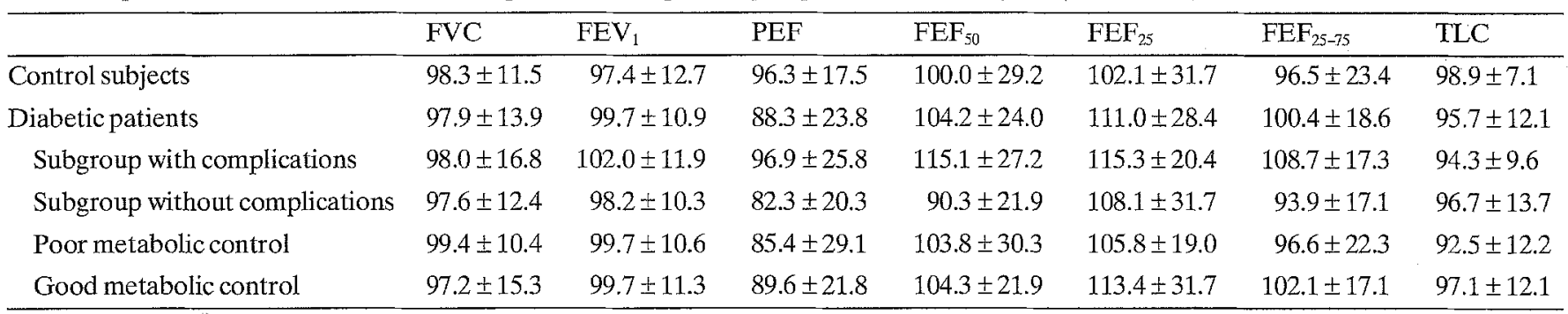

$\mathrm{FVC}$, Forced vital capacity; $\mathrm{FEV}_{1}$, forced expiratory flow in $1 \mathrm{~s} ; \mathrm{PEF}$, peak expiratory flow; $\mathrm{FEF}_{50}, \mathrm{FEF}_{25}$, forced expiratory flow when 50 or $25 \%$ of the forced vital capacity has been exhaled; $\mathrm{FEF}_{25-75}$, forced mild expiratory flow; TLC, total lung capacity

diabetic complications (six of them had background retinopathy, two manifested symptoms of nephropathy and in four patients symptoms of retinopathy, nephropathy and neuropathy co-existed). The remaining 19 subjects (11 men and eight women) were placed into the subgroup without complications. 2. Metabolic status. Data were taken from medical records kept at the clinic. The individual measurement of fructosamine and $\mathrm{HbA}_{1}$ alone cannot assess metabolic status $[5,6]$ when compared with life duration of structural proteins in the pulmonary system. Therefore, data of $\mathrm{HbA}_{1}$ and fructosamine were treated as supplementary. Twenty-two patients (11 men and 11 women) were assigned to the subgroup with good metabolic control which was defined as both fasting glycaemia below $7.77 \mathrm{mmol} / \mathrm{l}$ and lack of glycosuria in 24-h urine collections measured during routine visits every 3 months at the clinic over the past 2.5 years. The remaining nine subjects (six men and three women) with higher fasting glycaemia levels and glycosuria were placed in to the group with poor metabolic control.

\section{Methods}

The pulmonary function tests comprised the following measurements:

- spirometric and flow-volume curve parameters:forced vital capacity $(\mathrm{FVC})$, forced expiratory flow in $1 \mathrm{~s}\left(\mathrm{FEV}_{1}\right)$, peak expiratory flow (PEF), forced expiratory flow when $50 \%$ or $25 \%$ of the forced vital capacity has been exhaled $\left(\mathrm{FEF}_{50}\right.$ and $\mathrm{FEF}_{25}$, respectively), forced mild expiratory flow $\mathrm{FEF}_{25-75}$

- diffusing capacity for carbon monoxide using single breathholding method $\left(\mathrm{DlCO} \mathrm{SB}_{\mathrm{SB}}\right)[7]$ and specific diffusing capacity in relation to alveolar volume $(\mathrm{D} / \mathrm{VA})$. $\mathrm{DlCO}_{\mathrm{SB}}$ was corrected for haemoglobin level.

- total lung capacity (TLC) using the single breath helium dilution method was performed in conjunction with the determination of the transfer factor of the lung for carbon monoxide.

- dynamic compliance using the electrical subtraction method [8]. Oesophageal pressure was determined according to the technique of Milic-Emili et al. [9]. An oesophageal balloon inserted approximately $40 \mathrm{~cm}$ from the nares was connected by Jaeger polyethylene ca- theter to one chamber of a pressure transductor. The other chamber was connected to the mouthpiece. Volumes were measured by integrating the flow recorded using a pneumotachograph Transferscreen II (Jaeger, Würzburg, FRG). Pressure-volume data were recorded on an oscilloscope producing transoesophageal pressurepulmonary volume seen loop. The slope of the loop ( $\Delta$ volume/ $\Delta$ pressure) was dynamic compliance (mean value from at least five repeated measurements was accepted). Dynamic compliance was determined at $20\left(\mathrm{Cdyn}_{20}\right)$ and $60\left(\mathrm{Cdyn}_{60}\right)$ breaths per min at a constant tidal volume. Results of spirometry, flow-volume curve and diffusing capacity parameters were expressed as a percentage of predicted value according to Societas Europea Physiologie Clinicea Respiratoriae (SEPCR) guidelines [10] and Cdyn according to Begin et al. [11].

\section{Statistical analysis}

Statistical analysis was performed using Student's $t$-test and correlation parameters. Differences at less than the $5 \%$ level were accepted as significant.

\section{Results}

No disturbances in spirometric parameters were observed in any of the diabetic patients studied. All of these parameters were within the normal range and were not significantly different when compared to the control group (Table 2). Diffusing capacity as measured by $\mathrm{DlCO}_{\mathrm{SB}}$ was significantly lower in the subgroup with complications when compared to both the subgroup without complications $(p<0.001)$ and the control group $(p<0.005)$. D/VA in diabetic patients was significantly lower when compared to the control group $(p<0.05)$. In the subgroup with late complications $\mathrm{D} / \mathrm{VA}$ was significantly lower than in 
Table 3. Diffusing capacity $\left(\mathrm{DlCO}_{\mathrm{SB}}, \mathrm{D} / \mathrm{VA}\right)$ and dynamic compliance at 20 and 60 breaths per min $\left(\mathrm{Cdyn}_{20}\right.$, Cdyn 60 values in patient groups and control subjects (mean $\pm \mathrm{SD})$

\begin{tabular}{lclll}
\hline & $\mathrm{DlCO}_{\mathrm{SB}}$ & $\mathrm{D} / \mathrm{VA}$ & $\mathrm{Cdyn}_{20}$ & $\mathrm{Cdyn}_{60}$ \\
\hline Control subjects & $99.3 \pm 12.8$ & $89.4 \pm 12.9$ & $95.2 \pm 11.5$ & $83.2 \pm 13.3$ \\
Diabetic patients & $94.9 \pm 18.3$ & $80.3 \pm 13.1^{\mathrm{a}}$ & $84.0 \pm 17.0^{\mathrm{a}}$ & $60.1 \pm 15.0^{\mathrm{c}}$ \\
$\quad$ Subgroup with complications & $81.0 \pm 16.2^{\mathrm{b}, \mathrm{d}}$ & $69.9 \pm 9.1^{\mathrm{c}, \mathrm{d}}$ & $80.6 \pm 13.2^{\mathrm{b}}$ & $57.4 \pm 13.4^{\mathrm{c}}$ \\
Subgroup without complications & $104.0 \pm 13.7$ & $87.2 \pm 10.7$ & $86.2 \pm 19.3$ & $80.3 \pm 12.0^{\mathrm{b}}$ \\
Poor metabolic control & $94.6 \pm 15.9$ & $84.6 \pm 12.6$ & $85.6 \pm 18.8$ & $57.8 \pm 16.9^{\mathrm{c}}$ \\
Good metabolic control & $95.0 \pm 19.7$ & $81.4 \pm 13.1$ & $61.0 \pm 14.4^{\mathrm{c}}$ \\
\hline
\end{tabular}

${ }^{\mathrm{a}} p<0.05,{ }^{\mathrm{b}} p<0.005,{ }^{\mathrm{c}} p<0.001$ vs control; ${ }^{\mathrm{d}} p<0.001$ vs subgroup without complications

both the control group and subgroup without complications $(p<0.001$ respectively).

$\mathrm{Cdyn}_{20}$ was significantly lower in the diabetic patients than in the control group $(p<0.05)$. It was significantly lower in the subgroup with complications and patients with poor metabolic control as compared with the control subjects $(p<0.005)$. The mean value of $\mathrm{Cdyn}_{60}$ was significantly lower in all diabetic subgroups than in the control group (all $p<0.001$ ) as shown in Table 3 . No significant correlations between age, duration of diabetes and pulmonary parameters were found.

\section{Discussion}

In the selected group of 31 young diabetic patients we did not find spirometric disturbances. Lange et al. [3] in 265 non-selected diabetic patients had demonstrated that diabetes may be associated with reduced values of FEV1 and FVC. Results of investigations using similarly pre-selected groups of patients as performed by Sandler et al. [4, 12] and Schernthaner et al. [13] confirm our observations. However, Schulyer et al. [2] and Schnapf et al. [1] as well as Cooper et al. [14] observed a decrease of TLC in diabetic patients. In their opinion lower values of TLC may be associated with the damage to collagen and elastin fibres caused by the non-enzymatic glycation of proteins. However, a limited joint mobility co-existed in patients examined by Schnapf et al. [1].

In our study disturbances of gas transfer expressed by significant decrease of DICO ${ }_{\mathrm{SB}}$ and D/VA were found. As opposed to Sandler et al. [4, 12] we found diminished $\mathrm{DICO}_{\mathrm{SB}}$ and D/VA only in the group with late diabetic complications. Similar results were reported by Weir et al. [15]. According to Sandler et al. [12] diffusing disorders in diabetic patients were due to a diminished capillary blood volume component affecting diffusing capacity. Several reports on experimentally-induced diabetic animals have shown histopathological pulmonary changes including both typical microangiopathy in pulmonary vessels and thickening of alveolar membranes [16, 17]. Membrane and capillary blood volume components of diffusion were not assessed in our study. Cooper et al. [14] and Schulyer et al. [2] did not observe diffusion abnormalities in a group of patients similar to ours. In a previous study performed by us in a carefully selected group of 12 diabetic patients without complications we did not find diffusion capacity abnormalities [18].
We found reduced values of $\mathrm{Cdyn}_{20}$ and $\mathrm{Cdyn}_{60}$ particularly in the subgroup with complications and the poor metabolic control group. In our opinion our findings are not in direct opposition to those of Sandler et al. [4, 12] and Schulyer et al. [2] who found reduced elastic recoil in diabetic patients. These authors as well as Schernthaner et al. [13], who found normal elastic recoil, did not estimate the dynamic compliance but they measured static compliance and transpulmonary pressure. The dynamic compliance is estimated during the air flow through the airways, so the Cdyn value may depend on irregular ventilation of so called "slow" alveoli (which have wide bronchioles and compliant wall) and "fast" alveoli (which have wide bronchioles and stiff wall) [8]. Therefore pressure-volume curves constructed during breathing, especially at a rapid rate, yield values for dynamic compliance that are much lower than those obtained under static conditions. However, frequencydependent compliance can be used as a test of small-airway dysfunction $[19,20]$, and our results may indicate local mosaic abnormalities of lung elastic recoil rather than disturbances of air flow in small airways. Flow-volume curve parameters $\mathrm{FEF}_{25}, \mathrm{FEF}_{50}$ were normal in our patients. Hamlin et al. [21] considered the glycation effect of collagen as one of the key factors of alterations of connective tissue which may explain the change of elastic properties of the lungs. Our results may indicate that changes in elastic properties may precede abnormalities in gas transfer.

Lack of correlation between age, duration of diabetes mellitus and results of pulmonary function tests may indicate that the observed changes in pulmonary function are connected with metabolic status and the presence of diabetic complications.

Acknowledgements. The authors gratefully acknowledge Prof. Dr. J.Pudelski for professional support and helpful comments on the manuscript.

\section{References}

1. Schnapf BM, Banks RA, Silverstien JJ, Rosenbloom AL, Chesrocon SE, Longhlin GM (1984) Pulmonary function in insulindependent diabetes mellitus with limited joint mobility. Amer Rev Respir Dis 130: 930-932

2. Schulyer MR, Niewoehner DE, Inkley SR, Kohn R (1976) Abnormal lung elasticity in juvenile diabetes mellitus. Amer Rev Respir Dis 113: 37-41 
3. Lange P, Groth S, Mortensen J et al. (1987) Diabetes mellitus and lung function. A population study. Bull Eur de Physiopathol Resp 23 [Suppl 12]: 328 (Abstract)

4. Sandler M, Bunn A, Stewart R (1986) Pulmonary function in young insulin-dependent diabetic patients. Chest 90:670-675

5. Kennedy L, Mehl TD, Riley WT, Merimee TJ (1981) Non-enzymatically glycosylated serum protein in diabetes mellitus. Diabetologia 21:94-98

6. Paisey RB, MacFarlane DG, Scheriff JR, Hartog M, Slade RR, White DA (1980) The relationship between blood glycosylated haemoglobin and home capillary glucose levels in diabetics. Diabetologia 19: 31-34

7. Cotes JE, Hall AM (1970) Transfer factor for the lung; normal values in adults. In: Arcangeli P (ed) Normal values for respiratory function in men. Panimerva Medica, Turin, pp 327-343

8. Forster RE, Dubois AB, Briscoe WA, Fisher AB (1986) The lung. Physiologic basis of pulmonary function tests. Year Book Medical, Chicago, London

9. Milic-Emili J, Mead J, Turner JM, Glauser EM (1964) Improved technique for estimating pleural pressure from esophageal balloons. J Appl Physiol 19: 207-211

10. Quanjer PH (ed) (1983) Standarised lung function testing. Bull Eur Physiopath Resp 19 [Suppl 5]: 1-94

11. Begin R, Renzetti AD, Bigler AH, Watanabe S (1975) Flow and age dependence of airway closure and dynamic compliance. J Appl Physiol 38: 199-207

12. Sandler M, Bunn AE, Stewart RI (1987) Cross-section study of pulmonary function in patients with insulin-dependent diabetes. Am Rev Respir Dis 135:223-229

13. Schernthaner G, Hauber P, Kummer F, Ludwig H (1977) Lung elasticity in juvenile onset diabetes mellitus. Am Rev Respir Dis 116: 544-546
14. Cooper BG, Taylor R, Alberti KGMM, Gibson GJ (1990) Lung function in patients with diabetes mellitus. Resp Med 84: 235-239

15. Weir DG, Jennings PE, Hendy MS, Barnett AH, Sherwood P, Burg E (1988) Transfer factor for carbon monoxide in patients with and without microantiopathy. Thorax 43: 725-726

16. Kodolova IM, Lysenko IV, Saltykov BB (1982) Changes in the lung in diabetes mellitis. Arkh Patol 44: $35-40$

17. Ofulve F, Kida K, Thurlbeck WM(1988) Experimental diabetes and the lung. I Changes in growth, morphometry and biochemistry. Am Rev Respir Dis 137: 162-166

18. Ziora D, Strojek K, Sroczynski J, Oklek K (1989) Pulmonary function tests in diabetics. Eur Resp J 2 [Suppl 5]: 336s (Abstract)

19. Woolcock AJ, Vincent NJ, Macklem PT (1969) Frequency dependence of compliance as a test of obstruction in small airways. $\mathrm{J}$ Clin Invest 48: 1097-1106

20. Levinson RS, Metzger LF, Stanley NN et al. (1977) Airway function in sarcoidosis. Am J Med 62: 51-59

21. Hamlin CR, Kohn RR, Luschin JH (1975) Apparent accelerated aging of human collagen in diabetes mellitus. Diabetes 24: $902-$ 904

Received: 12 March 1992

and in final revised form: 27 August 1992

Dr. K. Strojek

Department of Internal and Occupational Diseases

Silesian Academy of Medicine

ul. 3-go Maja 13/15

PL-41-800 Zabrze

Poland 